\title{
Inclusive tourism as a method for rehabilitation and restoration of human well-being
}

\author{
Irina Churilina ${ }^{1}$, Lyubov Larchenko ${ }^{1}$, Timur Anisimov ${ }^{1}$, and Alexey Volkov ${ }^{1}$ \\ ${ }^{1}$ Herzen University, 48 Moika Embankment, Saint Petersburg, Russia
}

\begin{abstract}
The aim of the research is to study the impact of inclusive tourism on the subjective assessment of the well-being level of tourists with disabilities and tourists without disabilities. The article deals with the issues of the conceptual apparatus of inclusive tourism, the peculiarities of its organization in Russia, taking into account foreign experience. Moreover, the study highlights the issues of inclusive tourism that have an impact on human well-being. Based on a sociological survey, the attitude to inclusive tourism as a way of influencing the subjective feeling of wellbeing in people with disabilities and in people without functional impairments is analyzed. The results of the study show that people with disabilities not only visit exhibitions and theaters, but also travel around Russia and other countries. It is concluded that there are positive shifts of respondents towards the implementation of the idea of inclusive tourism, since there is a direct relationship between the number of travels and the well-being of respondents. It is emphasized that a wide questionnaire survey, discussion of inclusive tours is already influencing the formation of a new level of consciousness of all participants in the tourism market and even at this stage creates new opportunities for the formation of human well-being.
\end{abstract}

\section{Introduction}

Accessible tourism is a relevant area of tourism development around the world. Accessible tourism is associated with a barrier-free environment and is based on an international principle, enshrined in documents such as The Convention on the Rights of Persons with Disabilities, Standard Rules on the equalization of opportunities for persons with disabilities, adopted by resolution 48/96 of the UN General Assembly on 20.12.1993. In a broad sense, a barrier-free (accessible) environment is a safe, comfortable space for most people. In 1991, at the UNWTO General Assembly, a resolution "Creating tourism opportunities for handicapped peoples in the nineties" was adopted, which made it possible to use the term "barrier-free" in tourism not only for people with disabilities, but also for people with functional limitations due to health disorders that can be temporary, albeit long-term. Thus, the term "tourism for all" was introduced into the terminology of tourism. And in the modern world, the concept of "barrier-free", "accessible" is now interpreted as the absence of any barriers not only for people with disabilities, but also for the elderly, people with small children and people with functional impairments. In the Russian regulatory framework, these groups are united under the definition of "low-mobility 
population groups" (LMPG) and are described in detail in the sanitary Rules 59.13330.2016 "Accessibility of buildings and structures for persons with reduced mobility". In addition, in Russia, in order to implement an integrated approach to the formation of a barrier-free environment, it was decided to extend the state program "Accessible Environment" until 2025. This Program provides for ensuring the accessibility of priority social, transport and engineering infrastructure for low-mobility citizens. Thus, the Russian Federation, sharing the international principles of a barrier-free environment, strives to create all opportunities for the active involvement of people in the development of life, cultural and social space. It is important to note that the concept of "social tourism", which is addressed to citizens with disabilities, people with limited mobility, has been introduced into the Federal Law "On the Basics of Tourism Activities" and is aimed at forming measures of state support for this sphere of tourism. Analyzing the regulatory framework of the Russian Federation, we note that national standards have also been created that regulate the quality of services for designated categories of citizens and are aimed at the formation of hotel and tourist services of universal design. This is how the requirements for the equipment of hotel rooms and the requirements for organizing travel for people with limited mobility, disabled people and people with functional impairments are defined. Both Russian $[1,2,3,4,5]$ and foreign authors [6,7] are engaged in the problems of the formation and development of inclusive tourism. Taking into account the existing approaches to the formation of a tourism product for tourists with disabilities, we assume that it is inclusive tourism not accessible tourism as a phenomenon that will increase the subjective assessment of the level of well-being not only of tourists with disabilities, but also of tourists without disabilities. The hypothesis that was put forward taking into account the identified problem during the analysis of the literature, the opinions of participants in the Russian tourist services market is as follows first of all it is the tourists who do not have functional health disorders who are not ready to implement inclusive tours.

\section{Materials and methods}

The formulated hypothesis determined the nature and methods of the research: analysis of statistical data on the number of trips made by people with disabilities, the method of Internet survey, the method of comparison. At the first stage, the selection was made up of members of target groups involved in inclusive tourism in Russia, students and teachers of the Institute of Defectological Education and Rehabilitation and the Institute of Economics and Management of Herzen State Pedagogical University of Russia, tourists with disabilities who took part in testing tourist routes in St. Petersburg and the Leningrad region. The selection of the pilot study consisted of 60 people, of which 30 respondents have disabilities of various nosologies (vision - 10, hearing - 10, human musculoskeletal system (HMS) - 10), 28 respondents do not have disabilities, 2 respondents have temporary functional health disorders associated with the musculoskeletal system. Questionnaires were developed for respondents with disabilities (type 1 questionnaire, 6 questions) and without functional impairments (type 2 questionnaire, 4 questions). This number of questions was determined after consultation with defectologists and tour operator companies that implement tourist routes for invatourists. The respondents were asked questions aimed at identifying the essential characteristics of inclusive tourism; determining the relationship between the increase in the number of inclusive tours and the well-being of society; characteristics of interest in travel and material capabilities of the respondents.

To assess the capacity of the inclusive tourism market, the statistical data of Federal State Statistics Service (Russia) - Rosstat were used; to analyze the impact of inclusive tourism on human well-being, publications on this topic were studied among them are data from the public organization Center of Inclusive Tourism (St. Petersburg, Russia), reports 
of the participants of the All-Russian scientific conference in the format of a teleconference "Tourism for people with disabilities: current state and development potential" [8], reports and speeches of the Russian-Swedish conference "Inclusion: equal opportunities, employment" [9], the scientific-practical seminar "From rampant to digital space: issues of providing an accessible environment for people with limited mobility" [10], RussianSwedish online seminar "Possible routes for all" [11], III Forum "World accessible to all", section "Accessible tourism" [12].

\section{Results}

\subsection{Inclusive tourism as a space of equal opportunities}

Studying the methodological approaches to technologies and the organization of inclusive tourism that exist today in domestic practice, we note that the essence of this process is considered through the organization of tourism for people with disabilities, and an equal sign is put between such definitions as "wheelchair tourism (invatourism)", "paratourism", "social tourism", "rehabilitation tourism". According to the authors of the article, this approach to defining the essence of inclusive tourism is methodologically incorrect, since it does not take into account the most important function of inclusion - the involvement of a tourist/traveler in society, in a microgroup. Obviously, with such a statement of the question, it is necessary to deal with the social and pedagogical issues of organizing inclusive tourism, and here come across the field of pedagogical science and must consider the technologies of inclusive tourism not only from the point of view of general methods of designing tours, but also the content of excursions, information about the objects of display , norms and ethics of interaction of participants of inclusive tours. From our point of view, a truly inclusive tour, which we really consider as a space of equal opportunities with all the ensuing consequences, should be designed not only by specialists from the tourism industry, but with the obligatory participation of teachers, defectologists, culturologists and social entrepreneurs who have experience volunteering (inclusive volunteers). We also understand that different groups of tourists have opposite points of view on the need to develop and implement inclusive tours, which reduces the rehabilitation potential of tourism and human well-being. This contradiction can be partially overcome by the principle of universal design, which is used in the hotel business, transport accessibility and the organization of escort for inventors. However, for the formation of an inclusive tour, it is necessary to pay special attention to the content of tourist information, the peculiarities of the route, taking into account all participants of the trip. Obviously, such a task is much more difficult than the development of tours for groups of tourists with disabilities of the same nosology. In connection with the identified problem, we believe that in order to develop inclusive routes it is necessary to use the competencies that exist in the field of inclusive education and, accordingly, training for the field of inclusive tourism should be carried out in the interdisciplinary area of "tourism-special pedagogy". It seems that strengthening the issues of special pedagogical training of personnel for the sphere of inclusive tourism will make it possible to more effectively solve the issues of "involvement" of people with disabilities in the development of the socio-cultural space. This is an auxiliary hypothesis that we formulated for the study. The main hypothesis of the study is as follows: "inclusive tourism as a phenomenon will increase the subjective assessment of the level of well-being not only of tourists with disabilities, but also of tourists without disabilities." This hypothesis was put forward taking into account the identified problem during the analysis of the literature, the opinions of participants in the 
Russian tourist services market that, first of all, tourists who do not have functional health disorders are not ready to implement inclusive tours.

The need for this study is due to the fact that according to the estimates of the World Health Organization, more than 1 billion (approximately $15 \%$ of the world's population) of people have some form of disability; 110 million (2.2\%) to 190 million (3.8\%) people aged 15 and over experience functional difficulties. What is very important, WHO notes that disability rates will increase, as there is a problem of aging and deteriorating health of the world's population [13]. In this regard, the need to create inclusive tours becomes obvious already at the current stage of the development of the world, since this type of tourism provides equal opportunities, meets the third goal of sustainable development declared by the United Nations that is good health and well-being and eliminates discrimination.

The authors of the article draw attention to the fact that tourism in Russia has good economic potential [14], since today the contribution of tourism to world GDP is estimated at 8.9 trillion US dollars, which accounts for $10.3 \%$ of world GDP [8], while "calculations for Russia show ... that in 2020 the demand for domestic tourist services may grow by $24 \%$ " [15], and thanks to the state program aimed to stimulate domestic tourist trips (tourist cashback) during the pandemic crisis, total tour sales amounted to 6.5 billion rubles, which is $40 \%$ more than in the same period in 2019 [16]. It is also assumed that inclusive tourism can reach $20 \%$ of the tourist flow, and inclusive educational tours and excursion routes are and will continue to be especially popular with inclusive tourists [17].

Thus, once again the thesis is confirmed that travel is an important part of human wellbeing, since it is they that provide the opportunity to acquire intangible benefits in the form of new impressions and experiences [18], but for this the hospitality sphere must be fully prepared and equipped with all the necessary services and equipment [19], and in such a way that all participants of inclusive tourism do not feel any discrimination, but feel comfort and care. [20] Under favorable economic conditions, tourist travel grows exponentially, performs the functions of life support, socialization, communication, recreation and rehabilitation [21] and can serve as an indicator for assessing the economic development of the country $[22,23]$.

\subsection{Impact of inclusive tourism on citizens' perception of well-bei}

In the course of the pilot study, it was found that as of January 1, 2020, there were 11 million 875 thousand disabled people in Russia, so that per every thousand people there are 81 people with disabilities. (Table 1).

Table 1. The number of disabled people in the Russian Federation.

\begin{tabular}{|c|c|c|}
\hline & 2019 & 2020 \\
\hline Total number of people with disabilities (thousands of people) & $\mathbf{1 1 9 4 7}$ & $\mathbf{1 1 8 7 5}$ \\
\hline group 1 disability & 1433 & 1422 \\
\hline group 2 disability & 5356 & 5209 \\
\hline group 3 disability & 4488 & 4556 \\
\hline disabled children & 670 & 688 \\
\hline Total number of disabled people, per 1000 people & 81.4 & 80.9 \\
\hline
\end{tabular}

The gender and age characteristics of citizens with disabilities are presented in Table 2. Here, for the study, it was important to establish that there are more women with disabilities in the Russian Federation than men, especially over the age of 60-65 years, disabled male children $7.5 \%$ of the total number of men, disabled female children $4.4 \%$ of the total number of women. 
Table 2. The gender and age characteristics of citizens with disabilities.

\begin{tabular}{|c|c|c|c|c|c|c|}
\hline & \multicolumn{3}{|c|}{ On the $1^{\text {st }}$ of January 2019} & \multicolumn{3}{|c|}{ On the $1^{\text {st }}$ of January 2020} \\
\hline & \multirow{2}{*}{ totally } & \multicolumn{2}{|c|}{ gender } & \multirow[t]{2}{*}{ totally } & \multicolumn{2}{|c|}{ gender } \\
\hline & & $\mathrm{m}$ & $\mathrm{f}$ & & $\mathrm{m}$ & $\mathrm{f}$ \\
\hline $\begin{array}{c}\text { total number of disabled } \\
\text { people (thousands of people) }\end{array}$ & 11948 & 5183 & 6765 & 11877 & 5204 & 6673 \\
\hline children under the age of 18 & 671 & 382 & 289 & 689 & 394 & 295 \\
\hline older than working the age & 7791 & 2619 & 5172 & 7732 & 2653 & 5079 \\
\hline
\end{tabular}

Disabled citizens, over 15 years old, generally show interest in an active lifestyle, including travel, visiting cultural events (52\%), but $18 \%$ do not want to be active (Table 3 ).

Table 3. People with disabilities assess their ability to lead an active lifestyle.

\begin{tabular}{|c|c|c|c|c|c|}
\hline $\begin{array}{c}\text { Observation } \\
\text { years }\end{array}$ & $\begin{array}{c}\text { People with } \\
\text { disabilities } \\
\text { over the age of } \\
\mathbf{1 5} \text { (thousands } \\
\text { of people) }\end{array}$ & $\begin{array}{c}\text { Able to lead } \\
\text { an active } \\
\text { lifestyle (\%) }\end{array}$ & $\begin{array}{c}\text { Unable to lead } \\
\text { an active } \\
\text { lifestyle, health } \\
\text { or age does not } \\
\text { allow (\%) }\end{array}$ & $\begin{array}{c}\text { Have no } \\
\text { interest or } \\
\text { desire to lead } \\
\text { an active } \\
\text { lifestyle }\end{array}$ & Undefined \\
\hline 2016 & 12751 & 52.6 & 28.8 & 18.0 & 0.6 \\
\hline 2018 & 12111 & 58.8 & 27.0 & 13.1 & 0.1 \\
\hline
\end{tabular}

Russian citizens with disabilities make tourist trips to the regions of the country, as well as travel abroad (Table 4).

Table 4. Participation of disabled persons over the age of 15 in tourist or excursion trips.

\begin{tabular}{|c|c|c|}
\hline & \multicolumn{2}{|c|}{ All respondents (\%) } \\
\cline { 2 - 3 } & 2016 & 2018 \\
\hline Of them made a tourist or sightseeing trip in the last 12 months & 100 & 100 \\
\hline $\begin{array}{c}\text { people with disabilities aged 15 years or more, who have never made a } \\
\text { tourist or excursion trip - total }\end{array}$ & 13,8 & 21,9 \\
\hline $\begin{array}{c}\text { including for the reason } \\
\text { prefer to relax with a trip to the country, to rest with relatives and friends } \\
\text { in another area }\end{array}$ & 100 & 100 \\
\hline for health reasons & 12.1 & \\
\hline for family reasons & 46.7 & 81.1 \\
\hline can not afford it due to lack of funds & 8.6 & 16.7 \\
\hline lack of interest in such trips & 24.0 & 11.9 \\
\hline other reason & 4.9 & 1.7 \\
\hline
\end{tabular}

Analysis of reports and speeches, debates, opinions and questions within the framework of the mentioned above seminars and conferences showed that people with disabilities actively participate in social life, travel and are even ready to move to another region if there is a job of interest to them. It was also noted that the demand for affordable domestic tourism services is increasing, as is the demand for international inbound and outbound accessible tourism.

To study the impact of inclusive tourism on the well-being of citizens, a pilot anonymous survey was conducted.

Answers to the question "How often do you visit museums, exhibitions, concerts, performances and other cultural events?" were distributed as follows: $50 \%$ of respondents with hearing impairments, $60 \%$ of respondents with visual impairments and $30 \%$ with 
disorders of the musculoskeletal system noted that they attend such events 1-2 times a year. (Fig. 1).

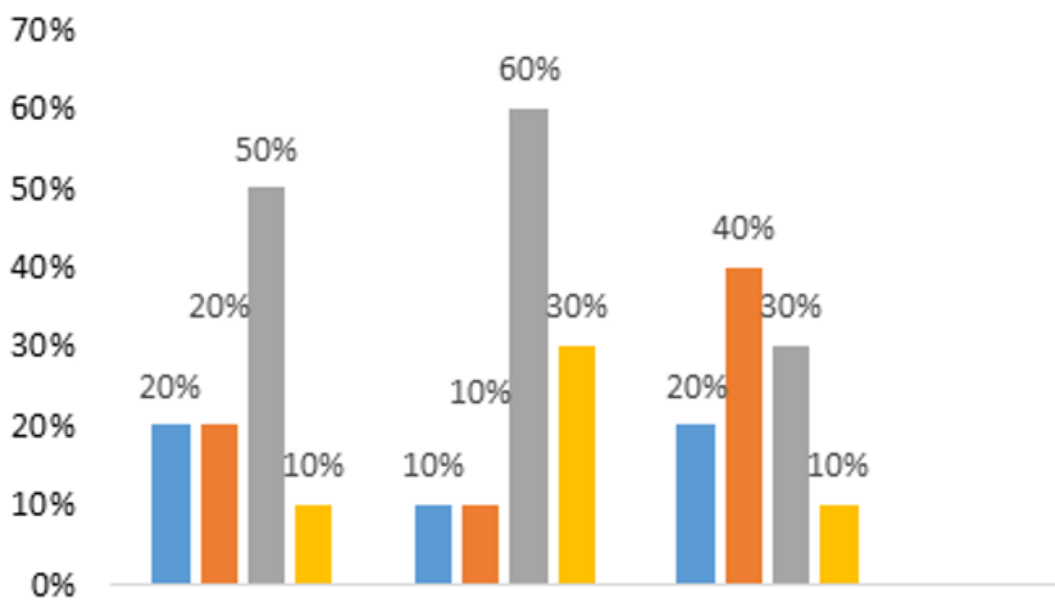

hearing disability vision disability musculoskeletal

\section{1-2 times a month}

1-2 times a year
1-2 times a quarter

1-2 times every few years

Fig. 1. Visits to cultural events by respondents with disabilities.

When asked how often the respondents travel to other countries, $80 \%$ of the respondents answered "never", $10 \%$ travel 1 time in their life, $10 \% 1$ time in several years. To the question of what travel gives the respondents, where the choice of answers was limited to two points, the following answers were received: to learn something new - $20 \%$; to find new friends - 5\%; to be inspired to become creative - $6.6 \%$; discover new qualities in themselves - $10 \%$; discover new opportunities - $11.7 \%$; a trip to the place of treatment (rehabilitation) - 35\%; other - $11.7 \%$. When asked with whom you would go on a trip, the respondents gave the following answers: $80 \%$ of the respondents will travel with a group of tourists who have about the same level of health; with a group that includes tourists with disabilities and tourists without disabilities - 6.6\%; it doesn't matter, the main thing is that everyone is comfortable - $3.4 \%$; find it difficult to answer - $3.4 \%$; together with accompanying persons $-6.6 \%$. Another important question was whether the respondents had experience of traveling in mixed groups. To this question $80 \%$ answered that they did not have such experience; $6.6 \%$ answered that they have such travel experience; $13,4 \%$ of respondents indicated that they travelled with accompanying persons.

The survey data for respondents without functional impairments showed that whether you would go on a trip as part of a group of tourists with disabilities, if the needs and opportunities for all $60 \%$ were taken into account; $23.4 \%$ of respondents are not ready for such a trip; have no experience of dealing with people with disabilities $10 \%$; other $-6.6 \%$. To the question of what the participants of the second group of respondents understand by inclusive tourism, we received the following answers: mixed groups of travelers - $66.7 \%$; only tourists with disabilities - $16.6 \%$; tourists with disabilities and their accompanying persons - $6.7 \%$; other - $10 \%$. An important question, in the light of the hypothesis formulated and the problem that accompanies it, is that if inclusive tours are actively developed, will the level of the well-being of society increase. This question was answered by both groups of respondents. The authors of the study obtained the following data: $68.3 \%$ 
of respondents agree that the level of well-being of the population will increase; $11.7 \%$ of participants do not see a connection between these phenomena; $8.3 \%$ of respondents could not answer the question; $11.7 \%$ of respondents have a different answer.

\section{Discussion. Opportunity and readiness for inclusive tourism of people with disabilities}

The data obtained in the course of the study allows us to formulate the main conclusions. The number of people with disabilities in the Russian Federation does not change much over the years and is kept at the level of 11-12 million people, which is approximately $7.5 \%$ of the total population. Among citizens with disabilities, the majority are women, this is due to the fact that the life expectancy in Russia for women today is higher than for men, and the mortality rate for men aged 20-35 is high for various reasons. The number of children with disabilities is $11.9 \%$ of the total number of disabled people. According to Rosstat, $52 \%$ of such citizens lead an active lifestyle, attend cultural events, travel, but 13\% lead a passive lifestyle. Such data suggest that for $13 \%$ of people with disabilities, a suitable socio-cultural space has not been created that would meet their individual needs or requests. In addition, according to statistics, we see that the number of people with disabilities who did not make a single trip in 2018 compared to 2016 increased by $8.1 \%$, since this is the percentage of respondents who could not afford it due to lack of funds. A worrisome trend was also the downward trend in health in 2018 compared to 2016 , in which $49 \%$ of respondents indicated as the reason why they were unable to travel.

A pilot survey conducted by the authors of the article confirmed the statistical data, and also made it possible to establish such trends in inclusive tourism as "travel to the place of treatment (rehabilitation)", the desire of the respondents to travel with accompanying persons, and $80 \%$ are ready to travel in a group with the same morbidity nosology and very few are willing to travel in mixed groups (3.4\%). Since our hypothesis, among other things, was determined by the degree of readiness for truly inclusive tourism of travelers without functional impairments, here we saw that $60 \%$ are ready to make inclusive tours, provided that "the needs of all participants in inclusive travel are taken into account." Nevertheless, $23.4 \%$ showed that they were not ready to become a participant in an inclusive tour.

\section{Conclusion}

Summing up our small research, which we plan to continue in 2021, we note the partial readiness of all respondents to implement the idea of inclusive tourism in understanding the concept of Extrability. In general, we found in the course of theoretical and empirical research that at present, under inclusive tourism, both people with disabilities and people without functional impairments understand tourism for people with disabilities in similar groups of diseases. Approximately the same understanding of inclusive tourism exists today in the Russian practice of organizing special tours. It seems to us that a wide questionnaire, discussion of inclusive tours is already influencing the formation of a new level of consciousness of all participants in the tourism market and even at this stage creates new opportunities for the formation of human well-being.

\section{References}

1. A.V. Bastrykina, Turizm v sisteme reabilitacii i social'noj integracii pozhilyh i lyudej s ogranichennymi vozmozhnostyami (1999). 
2. L.A. Mezhova, A.L. Letin, L.A. Lugovskaya. Teoriya i praktika organizacii inklyuzivnogo turizma v Rossii i za rubezhom. Sovremennye problemy nauki i obrazovaniya. 1 (2015).http://www.science-education.ru/ru/article/view?id=17354, accessed: 17.11.2020.

3. Yu. S. Konstantinov. Detsko-yunosheskij turizm. (2006).

4. N.M. Borisenko-Klepach, Inklyuzivnyj turizm: chto, kak i zachem? (2016).

5. I.N. Churilina, T.YU. Anisimov, E.V. Egorova, Problemy i perspektivy formirovaniya dostupnoj sredy dlya malomobil'nyh turistov v Sankt-Peterburge. Menedzhment XXI veka: antikrizisnye strategii i upravlenie riskami. 216-219 (2015).

6. D. Buhalis, S. Darcy, I. Ambrose, Best Practice in Accessible Tourism: Inclusion, Disability, Ageing Population and Tourism, (2012). https://www.researchgate.net/publication/235993171, accessed: 20.11.2020.

7. N. Varotsis. Quality Standards in Hospitality Industry: Ionian Region. https://www.longdom.org/open-access/quality, accessed: 25.11.2020.

8. All-Russian Scientific and Practical Conference«Turizm dlya lyudej s ogranichennymi vozmozhnostyami zdorov'ya: sovremennoe sostoyanie i potencial razvitiya» https://lengu.ru/conference/view?id=439, accessed: 27.11.2020.

9. Joint Russian-Swedish Conference «Inklyuziya: ravnye vozmozhnosti, trudoustrojstvo».https://www.gov.spb.ru/gov/otrasl/trud/news/178529/, accessed: 28.11.2020.

10. Reabilitaciya invalidov Samarskoj oblasti. Nauchno - prakticheskij seminar "Ot pandusov k cifrovomu prostranstvu: voprosy obespecheniya dostupnoj sredy dlya malomobil'nyh grazhdan". https://reabilit.samregion.ru/current-events/nauchnoprakticheskij-seminar-ot-pandusov-k-tsifrovomu-prostranstvu-voprosy-obespecheniyadostupnoj-sredy-dlya-malomobilnykh-grazhdan, accessed: 10.12.2020.

11. Russian Geographical Society project «Vsem Vozmozhnye Marshruty». https://www.rgo.ru/ru/article/nachalis-semki-novogo-sezona-vsemvozmozhnyhmarshrutov, accessed: 10.12.2020.

12. Forum «Mir dostupnyj dlya vsekh!». http://www.pressrelease.ru/branches/education/forum_mir_dostupnyy_dlya_vsekh_12_09_2020_12_0 8/, accessed: 01.12.2020.

13. Global website of the World Health Organization. https://www.who.int/ru/newsroom/fact-sheets/detail/disability-and-health, accessed: 15.11.2020.

14. T.P. Skufina, S.V. Baranov, V.P. Samarina., A.V. Samarin, Natural resources as a factor of socio-economic development of the Arctic territories: theoretical components of the research problem. IOP Conference Series: Earth and Environmental Science, 302, 1 (2019).

15. Tanina, O. Zaborovskaia, T. Shabunina, Y. Yakishin, Conceptual bases of development of tourism in municipal formation (on an example of Gatchina municipal area), Proceedings of the 32nd International Business Information Management Association Conference, 3216-3222 (2018).

16. A.A. Zajcev, A.A. Tihonov, Obzor vliyaniya pandemii koronavirusa na turisticheskuyu otrasl'. Analiticheskij byulleten' NIU VSHE ob ekonomicheskih i social'nyh posledstviyah koronavirusa v Rossii i v mire. 6 (2020).

17. Official city tourist portal of St. Petersburg. https://www.visitpetersburg.ru/search/?searchid $=2225809 \&$ web=0\&text=dostupnaya+sreda, accessed: 30.10.2020. 
18. L. V. Larchenko, Yu.N. Gladkiy, R.A. Kolesnikov, Tourism as a factor of restructuring the economy of resource-producing regions of the Arctic (on the example of the Yamalo-Nenets Autonomous District). IOP Conference Series: Earth and Environmental Science. 302, 012039 ( 2019).

19. A.V. Kuchumov, G.A. Karpova, Y.T. Testina, Application of smart technologies for the development of a region: A case study on tourism industry in St. Petersburg. ACM International Conference Proceeding Series, https://www.elibrary.ru/item.asp?id=41597218, ( 2020).

20. A.V. Kuchumov, N.V. Zigern-Korn, Ya.S. Testina, Yu.M. Boykova, Development Trends of the Tourism Clusters in the Russian Federation. IOP Conference Series: Earth and Environmental Science, 204, 012021(2018).

21. V.Samarina, T. Skufina, A. Samarin, E. Korchak, N. Serova. Conceptual Fundamentals and Key Priorities of the Circumpolar States' Arctic Policies /35th InternationalBusiness-Information-Management-Association (IBIMA) Conference. Vision 2025 (2020).

22. Statistical Bulletin of Rosstat for World Tourism Day.https://rosstat.gov.ru/storage/mediabank/7ZtU1mUD/turizm-2020.docx, accessed: 06.11.2020.

23. E.G. Kiyakbaeva, Analiz indikatorov ustojchivogo razvitiya turizma. https://cyberleninka.ru/article/n/analiz-indikatorov-ustoychivogo-razvitiyaturizma/viewer, accessed: 18.10.2020. 